DOI: $10.47743 /$ jss-2021-67-4-11

\title{
Executarea acordurilor încheiate prin mijloace electronice rezultate din mediere în litigiile de comerţ internaţional în baza Convenţiei de la Singapore
}

\section{Enforcement of Settlement Agreements Resulting from Mediation Concluded by Electronic Communication in International Trade Disputes under the Singapore Convention}

\author{
Ionela-Diana Pătraşc-Bălan ${ }^{1}$
}

Rezumat: Principala reticienţă a părţilor în a soluţia litigiile de comerţ internaţional prin mediere a fost lipsa forţei executorii a acordului de mediere. The United Nations Convention on International Settlement Agreements Resulting from Mediation (the Singapore Convention), Convenţia Naţiunilor Unite cu privire la acordurile internaţionale rezultate din mediere (Convenţia de la Singapore) este primul instrument multilateral care reglementează problematica referitoare la recunoaşterea şi executarea acordurilor de mediere internaţionale încheiate în materie comercială. Prin prezentul articol ne propunem să analizăm condiţiile în care un acord de mediere şi, în particular, un acord de mediere încheiat prin mijloace electronice poate fi pus în executare conform Convenţiei de la Singapore.

Cuvinte-cheie: Convenţia de la Singapore; acord de mediere; mijloace electronice; punere în executare

\begin{abstract}
The main reluctance of the parties to resolve international trade disputes through mediation was the lack of enforceability of settlement agreement resulting from mediation. The United Nations Convention on International Settlement Agreements Resulting from Mediation (the Singapore Convention) is the first multilateral instrument to regulate the recognition and enforcement of international settlement agreements resulting from mediation concluded in commercial matters. This article aims to examine the conditions under which a settlement agreement resulting from mediation and, in particular, a settlement agreement concluded by electronic communication is enforceable in accordance with the Singapore Convention.
\end{abstract}

Keywords: Singapore Convention; settlement agreement resulting from mediation; electronic communication; enforceability

\footnotetext{
${ }^{1}$ Doctorand, Facultatea de Drept, Universitatea „Alexandru Ioan Cuza” din Iaşi, e-mail: dianapat27@yahoo.com.
} 


\section{Introducere}

Pentru soluţionarea diferendelor ivite în executarea relaţiilor comerciale internaţionale părţile au la dispoziţie mai multe mijloace ${ }^{2}$ : negocierea, modalitate de rezolvare a neînţelegerilor prin discuţii directe; medierea/concilierea sau alte forme de soluţionare voluntară asimilate, intermediate de un terţ care asistă şi ajută părţile să ajungă la o înţelegere; arbitrajul, procedură care se desfăşoară prin intermediul unui tribunal arbitral şi se finalizează cu o decizie obligatorie; instanţele de judecată care pronunţă hotărâri obligatorii pentru litiganţi.

Printre elementele care diferenţiază aceste modalităţi de rezolvare a diferendelor putem identifica caracterul executoriu al actului final al procedurii de soluţionare a diferendelor, executorialitatea fiind prezentă în cazul hotărârilor arbitrale şi a celor judecătoreşti. Potrivit unui studiu realizat de Singapore International Dispute Resolution Academy (SIDRA), principalul criteriu în alegerea unui mijloc de soluţionare a litigiilor pentru $71 \%$ dintre respondenţi îl reprezintă forţa executorie a hotărârii prin care se soluţionează diferendul ${ }^{3}$.

Medierea este inclusă în categoria mijloacelor alternative de soluţionare a litigiilor ${ }^{4}$. Indiferent dacă medierea este $a d$-hoc sau instituţionalizată, desfăşurată prin intermediul unui centru de arbitraj, acest mijloc de soluţionare a neînţelegerilor dintre părţi presupune intervenţia unui terţ al cărui rol este acela de a le asista în încercarea de a ajunge la un acord de soluţionare, de a facilita semnarea acordului, fără a putea impune o soluţie ${ }^{5}$.

2 J. W. Salacuse, Is There a Better Way? Alternative Methods of Treaty-Based, InvestorState Dispute Resolution, în Fordham International Law Journal, Volume 31, Issue 12007 Article 6, p. 154, [Online] la https://core.ac.uk/download/pdf/144226963.pdf, accesat 20.09.2021.

${ }^{3}$ SIDRA International Dispute Resolution Survey: 2020 Final Report, p. 7, [Online] la https://sidra.smu.edu.sg/sites/sidra.smu.edu.sg/files/survey/50/index.html, accesat 12.09.2021.

${ }^{4}$ Conform SIDRA, op. cit., p. 7, sintagma „mijloace alternative de soluţionare a litigiilor” (Alternative Dispute Resolution, $A D R$ ) a început să fie utilizată la mijlocul anilor 1970 în Statele Unite ale Americii; Într-o accepțiune exprimată de S.D. Franck, Challenges Facing Investment Disputes: Reconsidering Dispute Resolution in International Investment Agreements. Appeals mechanisms in international investment disputes, Karl P. Sauvant, ed., Oxford University Press, 2008, Washington \& Lee Legal Studies Paper No. 2009-03, p. 158, [Online] la https://papers.ssrn.com/sol3/papers.cfm?abstract_id=1427590, accesat 22.02.2021, în ADR sunt incluse modalități de soluționare a litigiilor altele decât prin intermediul instanțelor; Într-o a doua interpretare exprimată în United Nations Conference On Trade And Development, Investor-State Disputes: Prevention and Alternatives to Arbitration II, United Nations New York and Geneva, 2011, p. xii, [Online] la https://unctad.org/system/files/official-document/webdiaeia20108_en.pdf, accesat 18.02.2021, prin ADR se înțelege modalitatea de rezolvare a diferendelor dintre părți, alta decât metodele primare de soluționare a disputelor, respectiv procedurile desfășurate în fața instanțelor de judecată statale sau în față instanțelor arbitrale internaționale.

${ }^{5}$ Idem; C. Kessedjian, Droit du commerce international, Ed. Presse Universitaires de France, Paris, 2013, p. 447; C.T. Ungureanu, Enforcement of the post- mediation agreement in 
O mediere de succes se finalizează prin încheierea unei înţelegeri numită acord de mediere. Deşi avantajele medierii faţă de celelalte metode de soluţionare a litigiilor de comerţ internaţional sunt recunoscute (costuri financiare şi durată de soluţionare reduse, păstrarea relaţiilor dintre contractanţi, confidenţialitate, libertatea de a alege regulile de procedură $)^{6}$, principalul său dezavantaj a fost identificat ca fiind lipsa forţei executorii a acordului de mediere ${ }^{7}$, precum şi inexistenţa unui cadru juridic internaţional unitar pentru punerea în executare a acordurilor de mediere ${ }^{8}$.

În legislaţiile care reglementează soluţionarea litigiilor prin mediere, acordul de mediere are natura juridică a unui contract ${ }^{9}$. Această calificare lipseşte acordul de mediere de forţa executorie a unei sentinţe arbitrale sau a unei hotărâri judecătoreşti. Acordul de mediere rezultat în urma soluţionării unui litigiu comercial internaţional nu poate fi recunoscut sau pus în executare direct în temeiul instrumentelor internaţionale care reglementează domeniul recunoaşterii şi executării sentinţelor arbitrale străine sau a hotărârilor judecătoreşti străine, respectiv Convenţia Naţiunilor Unite pentru recunoaşterea şi executarea sentinţelor arbitrale străine încheiată la New York în 1958 (Convenţia de la New York $)^{10}$, Convenţia din 18 martie 1965 pentru reglementarea diferendelor relative la investiţii între state şi persoane ale altor state (Convenţia de la Washington) ${ }^{11}$, Convenţia din 30 iunie 2005 privind acordurile de alegere a forului (Convenţia de la Haga $)^{12}$.

international trade disputes, în Modernizarea legislației naționale în contextul uniformizării dreptului la nivel european și implicațiile socio-politice asupra sistemului administrativ, Editura Hamangiu, București, 2014, p. 279.

${ }^{6}$ C. Kessedjian, op. cit., p. 447; C.T. Ungureanu, op. cit., p. 279; T. Schnabel, The Singapore Convention on Mediation: A Framework for the Cross-Border Recognition and Enforcement of Mediated Settlements (September 18, 2018). 19 Pepp. Disp. Resol. L.J. 1 (2019), [Online] la https://ssrn.com/abstract=3239527 or http://dx.doi.org/10.2139/ssrn.3239527, p. 2, accesat 13.02.2021; M. Sîrbu, Metodele ADR în contextul european și internațional, Editura Universul Juridic, București, 2020, pp. 78-79.

${ }^{7}$ J. W. Salacuse, op. cit., p. 179; C.T. Ungureanu, op. cit., p. 280; T. Schnabel, op. cit., p. 2; M. Sîrbu, op. cit., p. 131.

${ }^{8}$ C. Jura, O introducere în materia Convenţiei Naţiunilor Unite privind Acordurile Internaţionale Rezultate în urma Medierii - Convenţia de la Singapore, în Revista română de arbitraj nr. 1/2020, [Online] la https://sintact.ro/\#/publication/151017435?keyword= conventia\%20de\%20la\%20singapore \&cm=SREST, accesat 12.09.2021.

${ }^{9}$ C. Kessedjian, op. cit., p. 451; C.T. Ungureanu, Punerea în executare ..., op. cit., p. 280.

${ }^{10}$ Textul convenției este disponibil [Online] la https://uncitral.un.org/sites/uncitral. un.org/files/media-documents/uncitral/en/new-york-convention-e.pdf, accesat 28.10.2021; România a aderat la această convenție prin Decretul nr. 186/10.06.1968 publicat în B.O. nr. 19 din 24.07.1961.

11 Textul convenției este disponibil [Online] la https://icsid.worldbank.org/sites/default/ files/ICSID\%20Convention\%20English.pdf, accesat 28.10.2021.

${ }^{12}$ Textul convenției este disponibil [Online] la https://op.europa.eu/ro/publicationdetail/-/publication/196d3251-fa6f-11e7-b8f5-01aa75ed71a1/language-ro, accesat 28.10.2021; UE a semnat Convenția de la Haga prin Decizia Consiliului din 26 februarie 2009 
În practică, pentru a înlătura acest dezavantaj, s-a apelat la o ficţiune juridică. În situaţia în care părţile au ajuns la încheierea unui acord de mediere după regulile elaborate şi propuse de ICSID, pentru a suplini lipsa caracterului executoriu al acordului de mediere, a fost avansată ipoteza încorporării sale într-o sentinţă arbitrală conform art. 43 alin. (2) din ICSID Arbitration Rules ${ }^{13}$. În această modalitate, acordul de mediere putea beneficia de procedura mecanismului de executare a Convenţiei de la Washington. $\mathrm{Cu}$ toate acestea, rămânea deschisă problematica referitoare la compatibilitatea utilizării unei proceduri similare de pronunţare a unei sentinţe cu privire la acordul de mediere (numirea mediatorului arbitru $a d$-hoc şi inserarea acordului de mediere în cuprinsul unei sentinţe arbitrale) cu mecanismul de punere în executare a sentinţelor arbitrale în baza Convenţiei de la New York ${ }^{14}$. În spaţiul UE, acordurile de mediere transfrontalieră care îmbracă forma unui înscris notarial sau a unei hotărâri judecătoreşti prin care s-a luat act de înţelegerea părţilor pot fi puse în executare în temeiul Regulamentul (UE) nr. 1215/2012 al Parlamentului European şi al Consiliului din 12 decembrie 2012 privind competenţa judiciară, recunoaşterea şi executarea hotărârilor în materie civilă şi comercială ( Regulamentul (UE) nr. 1215/2012) $)^{15}$.

Pentru a înlătura principalul dezavantaj al utilizării medierii ca mijloc alternativ de soluţionare a litigiilor de comerţ internaţional a fost adoptată la 20 decembrie 2018 United Nations Convention on International Settlement Agreements Resulting from Mediation (Singapore Convention on Mediation, Singapore

privind semnarea în numele Comunității Europene a Convenției privind acordurile de alegere a forului, publicat în OJ L 133, 29.5.2009; UE a aprobat Convenția de la Haga prin Decizia Consiliului din 4 decembrie $2014 \mathrm{cu}$ privire la aprobarea, în numele Uniunii Europene, a Convenției de la Haga din 30 iunie 2005 privind acordurile de alegere a forului, publicată în OJ L 353, 10.12.2014. Convenția de la Haga a intrat în vigoare la 1 octombrie 2015.

${ }^{13}$ Art. 43 alin. (2) din ICSID Arbitration Rules; ICSID Arbitration Rules pot fi consultate [Online] la https://icsid.worldbank.org/resources/rules-and-regulations/convention/ arbitration-rules, accesat 30.09.2021.

${ }^{14}$ B.L. Steele, Enforcing International Commercial Mediation Agreements as Arbital Awards Under the New York Convention în 54 UCLA Law Review 1385 (2007), pp. 1397-1399, [Online] la https://www.uclalawreview.org/enforcing-international-commercialmediation-agreements-as-arbital-awards-under-the-new-york-convention/, accesat 30.09.2021; E. Sussman, The New York Convention Through a Mediation Prism, în Dispute Resolution Magazine Volume 15, Number 4, Summer 2009, [Online] la https://sussmanadr.com/docs/NY\%20Coinvention\%20Prism\%20ABA\%20DR\%20as\%20print ed-\%20white\%20background\%208-09.pdf, accesat 30.09.2021.

${ }^{15}$ Publicat în JO L 351, 20.12.2012; Textul regulamentului este disponibil la adresa https://eur-lex.europa.eu/legal-content/ro/TXT/?uri=CELEX\%3A32012R1215, accesat 28.10.2021; Pentru executarea acordului de mediere în UE, a se vedea C.T. Ungureanu, Punerea în executare ..., op. cit., pp. 282-283. 
Convention), Convenţia Naţiunilor Unite cu privire la acordurile internaţionale rezultate din mediere (Convenţia de la Singapore) ${ }^{16}$.

\section{Convenţia de la Singapore}

Acest tratat multilateral se alătură şi întregeşte cadrul juridic internaţional în materia recunoaşterii şi executării actelor finale rezultate în urma soluţionării litigiilor de comerţ internaţional, alcătuit din Convenţia de la New York, care se aplică pentru recunoaşterea şi executarea sentinţelor arbitrale străine şi Convenţia de la Haga din 2005, care reglementează recunoaşterea şi executarea hotărârilor judecătoreşti străine ${ }^{17}$.

Scopul principal al Convenţiei de la Singapore este acela de a promova medierea ca mijloc de soluţionare a litigiilor de comerţ internaţional. Preambulul tratatului internaţional reafirmă câteva dintre avantajele certe ale medierii: menţinerea relaţiilor contractuale, facilitarea operaţiunilor de comerţ internaţional, economii în administrarea justiţiei statale ${ }^{18}$.

Pe lângă noutatea reglementării domeniului medierii printr-un tratat multilateral, adoptarea Convenţiei de la Singapore marchează încă o premieră: UNCITRAL a dezvoltat într-un pachet legislativ două instrumente cu forţă juridică diferite $^{19}$ : convenţia, act normativ obligatoriu şi legea model, reglementare de tip soft-law, UNCITRAL Model Law on International Commercial Mediation and

16 Textul Convenției de la Singapore este disponibil [Online] la https://uncitral.un. org/sites/uncitral.un.org/files/media-documents/EN/Texts/

UNCITRAL/Arbitration/mediation_convention_v1900316_eng.pdf, accesat 30.10.2021; Inițiativa adoptării acestui instrument internațional a aparținut în anul 2014 Statelor Unite ale Americii care a înaintat propunerea privind promovarea sa în contextul dezbaterii privind transparența în arbitrajele investiționale în interiorul Grupului de lucru II din cadrul UNCITRAL. Deși în cadrul discuțiilor purtate pentru adoptarea Convenției de la Singapore, UE şi unele SM s-au opus proiectului, acesta a fost adoptat în cele șase sesiuni de lucru ale grupului de lucru dedicate acestui subiect; A se vedea în acest sens, T. Schnabel, op. cit., p. 4. La data deschiderii pentru semnare, Convenția a fost semnată de 46 de state incluzând primele două cele mai mari economii mondiale (SUA și China). Convenția de la Singapore a intrat în vigoare la 12 septembrie 2020. Până la 30 octombrie 2021, această convenție a fost semnată de 55 de state și ratificată de către opt dintre acestea. Lista statelor semnatare părți la Convenție este disponibilă [Online] la https://www. singaporeconvention.org/jurisdictions, accesat 30.10.2021.

${ }^{17} \mathrm{La} 2$ iulie 2019 a fost încheiată Convention on the recognition and enforcement of foreign judgments in civil or commercial matters. Textul Convenției este disponibil [Online] la https://assets.hcch.net/docs/806e290e-bbd8-413d-b15e-8e3e1bf1496d.pdf, accesat 30.10.2021.

La acest moment, această convenție nu a intrat în vigoare.

${ }_{18}$ Preambulul Convenției de la Singapore, al treilea alineat.

${ }^{19}$ T. Schnabel, op. cit., p. 7. 
International Settlement Agreements Resulting from Mediation, 2018 ${ }^{20}$. Aceste două reglementări se aplică complementar ${ }^{21}$.

Adoptată iniţial în anul 2002 sub titulatura Model Law on International Commercial Conciliation, actuala formă a Legii model modificată în anul 2018 aduce în plus, pe lângă o schimbare de terminologie (termenul „conciliere” a fost înlocuit cu termenul „mediere”), un capitol ce se referă la acordurile internaţionale de mediere şi punerea lor în executare. Scopul noii versiunii a Legii model a fost acela de ajuta statele să adopte sau să îşi modernizeze legislaţia în materia medierii, şi, totodată, de a fi un instrument util în aplicarea Convenţiei de la Singapore ${ }^{22}$. UE a susţinut această modificare a Legii model, argumentând că vechea formă din 2002 conţinea reglementări care veneau în contradicţie cu Directiva 2008/52/EC ${ }^{23}$.

\subsection{Punerea în executare a acordului rezultat din mediere}

În temeiul Convenţiei de la Singapore, acordul de mediere va putea fi pus în executare pe teritoriul unui stat parte la această convenţie printr-o procedură similară punerii în executare a unei hotărâri arbitrale străine sau unei hotărâri judecătoreşti străine, conform procedurilor reglementate de Convenţia de la New York, respectiv de Convenţia de la Haga. Operatorii de comerţ internaţional aflaţi în posesia unui acord de mediere se vor adresa direct autorităţilor competente din statul solicitat pentru punerea în executare a acordului de mediere.

În caz de neexecutare, partea interesată poate solicita punerea în executare a acordului de mediere conform art. 3 alin. (1) din Convenţia de la Singapore. Totodată, acordul de mediere poate constitui un mijloc de apărare în cadrul unui litigiu declanşat ulterior asupra unei chestiunii ce a fost tranşată între părţi prin acordul de mediere (art. 3 alin. (2) din Convenţia de la Singapore).

Spre deosebire de Convenţia de la New York care foloseşte în titulatura sa termenul „recunoaşte” şi termenul „executare” în legătură cu sentinţele arbitrale străine, Convenţia de la Singapore nu utilizează sintagma „recunoaşterea acordului

${ }^{20}$ Textul Legii model este disponibil [Online] la https://uncitral.un.org/sites/ uncitral.un.org/ files/media-documents/uncitral/en/annex_ii.pdf., accesat 30.10.2021.

${ }^{21}$ N.Y. Morris-Sharma, Constructing the Convention on Mediation: The Chairperson's Perspective (2019) 31 Singapore Academy of Law Journal 487-519 p. 29, [Online] la https://journalsonline.academypublishing.org.sg/Journals/Singapore-Academy-of-LawJournal-Special-Issue/e-

Archive/ctl/eFirstSALPDFJournalView/mid/513/ArticleId/1468/Citation/JournalsOnlinePD $\mathrm{F}$, accesat 12.09.2021.

${ }^{22}$ UNCITRAL Model Law on International Commercial Mediation and International Settlement Agreements Resulting from Mediation, 2018, [Online] la https://uncitral.un.org/ en/texts/mediation/modellaw/commercial_conciliation, accesat 12.09.2021.

${ }^{23} \mathrm{~N}$. Alexander, S. Chong, UN Treaty on mediation signed in Singapore, NederlandsVlaams tijdschrift voor mediation en conflictmanagement. 23, (2-3), 71-76, 2019 Singapore Management University School of Law Research Paper No. 14/2020, p. 75, [Online] la https://papers.ssrn.com/sol3/papers.cfm?abstract_id=3583399, accesat 11.09.2021; Directiva 2008/52/CE a Parlamentului European și a Consiliului din 21 mai 2008 privind anumite aspecte ale medierii în materie civilă și comercială, publicată în JO L 136, 24.5.2008. 
de mediere". Redactorii tratatului multilateral au optat pentru o abordare funcţională. Prin dispoziţiile art. 3 alin. (2) din Convenţia de la Singapore au fost reglementate efectele instituţiei „recunoaşterii” acordului de mediere, dar nu a fost utilizată expressis verbis această noţiune ${ }^{24}$. Soluţia finală este rezultatul opoziţiei manifestate în timpul negocierilor de către unele state, care au argumentat că termenul „recunoaştere” poate fi asociat doar în legătură cu hotărârile judecătoreşti, şi nu în legătură cu înţelegeri dintre particulari, întrucât efectul de res judicata poate fi ataşat doar acestora ${ }^{25}$. Aceasta nu semnifică faptul că acordul de mediere nu poate fi recunoscut, întrucât o parte poate invoca acordul de mediere în faţa instanţei pentru a putea dovedi că problema dedusă judecăţii a fost deja soluţionată prin acordul de mediere în situaţia în care este chemată în judecată pentru o chestiune litigioasă dezlegată printr-un acord anterior de mediere ${ }^{26}$.

Conform art. 3 pct. 1 din Convenţia de la Singapore care consacră principiul autonomiei procedurale, fiecare stat parte la convenţie va aplica propriile norme de procedură pentru punerea în executare a acordului de mediere în condiţiile prevăzute de tratatul multilateral ${ }^{27}$.

\subsection{Formalităţi pentru punerea în executare a acordului de mediere}

Pentru a pune la dispoziţia părţilor un instrument internaţional flexibil şi atractiv, redactorii Convenţiei de la Singapore au prevăzut condiţii minime în ceea ce priveşte formalităţile pe care părţile trebuie să le îndeplinească pentru executarea acordului de mediere ${ }^{28}$.

În vederea punerii în executare, partea interesată va adresa autorităţii competente din statul solicitat parte la Convenţia de la Singapore, care trebuie să fie altul decât statul în care a fost încheiat acordul, o cerere, la care va anexa acordul de mediere semnat de către părţi şi dovada împrejurării că această înţelegere

${ }^{24}$ N.Y. Morris-Sharma, op. cit., p. 500; T. Schnabel, op. cit., p. 37; S. Chong, F. Steffek, Enforcement of International Settlement Agreement Resulting from mediation under the Singapore Convention - Private International Law Issues in Perspective", Singapore Academy of Law Volume 31 (2019), p. 465, [Online] la https://journalsonline. academypublishing.org.sg/Journals/Singapore-Academy-of-Law-Journal-Special-Issue/eArchive/ctl/eFirstSALPDFJournalView/mid/513/ArticleId/1467/Citation/JournalsOnlinePD F., accesat 12.09.2021; K. McCormick, S.S. M. Ong, "Through the Looking Glass: An Insider's Perspective into the Making of Singapore Convention on Mediation" (2019) 31 Singapore Academy of Law Journal, p. 534, [Online] la https://journalsonline. academypublishing.org.sg/Journals/Singapore-Academy-of-Law-Journal-Special-Issue/eArchive/ctl/eFirstSALPDFJournalView/mid/513/ArticleId/1471/Citation/JournalsOnlinePD F, accesat 12.09.2021.

${ }^{25}$ N.Y. Morris-Sharma, op. cit., p. 502; T. Schnabel, op. cit., p. 35.

${ }^{26}$ Art. 3 alin. (2). din Convenția de la Singapore.

${ }^{27}$ Art. 3 pct. 1 din Convenția de la Singapore.

${ }^{28}$ D. Q. Anderson, The Singapore Convention on Mediation: Supplying the Missing Piece of the Puzzle for Dispute Resolution, p. 11, Forthcoming, Journal of the Malaysian Judiciary (Nov 2020), Singapore Management University School of Law Research Paper No. 1/2020, available at SSRN: https://ssrn.com/abstract=3553739, accesat 30.10.2021. 
privind soluţionarea diferendului este rezultată în urma medierii ${ }^{29}$. Astfel cum rezultă din textul reglementării, aceste condiţii sunt limitative. Statele părţi la Convenţia de la Singapore nu pot impune alte condiţii ${ }^{30}$.

Dovada că acordul prezentat de către părţi este rezultatul procesului de mediere poate fi făcută în una dintre următoarele modalităţi: a) acordul de mediere să poarte semnătura mediatorului; b) se prezintă un document semnat de către mediator care atestă împrejurarea că medierea a fost efectuată sau c) un certificat de la instituţia care a administrat medierea; d) se poate prezenta orice altă dovadă acceptată de autoritatea competentă a statului în care se solicită executarea acordului de mediere ${ }^{31}$.

\subsection{Amânarea recunoașterii sau executării acordului de mediere}

Această procedură este prevăzută la art. 6 din Convenţia de la Singapore ${ }^{32}$.

În situaţia în care acordul de mediere a cărui recunoaştere sau executare se solicită face obiectul unei acţiuni în faţa instanţelor judecătoreşti, arbitrale sau a unei alte autorităţi competente şi această cerere este de natură să afecteze cererea formulată în temeiul Convenţiei de la Singapore, redactorii tratatului multilateral asupra medierii au prevăzut posibilitatea ca autoritatea competentă căreia i se solicită recunoaşterea sau executarea să poată amâna decizia asupra acestei cereri, solicitând părţii o garanţie adecvată.

Din textul reglementării rezultă împrejurarea că amânarea este o opţiune lăsată la îndemâna autorităţii competente a statului solicitat, şi nu o obligaţie, procedura executării putând continua şi în aceste circumstanţe.

\section{Acordurile care pot fi puse în executare în baza Convenţiei de la Singapore}

Convenţia de la Singapore nu este incidentă în cazul tuturor acordurilor rezultate din medierea internaţională, domeniul său de aplicare ratione materiae şi ratione temporis fiind delimitat prin chiar prevederile tratatului internaţional.

\subsection{Ratione materiae}

Convenţia de la Singapore se aplică: „oricărui acord ce rezultă din mediere şi este încheiat în scris de către părţi pentru rezolvarea unui litigiu comercial (acord de soluţionare) care la momentul încheierii este internaţional..." ${ }^{\text {33. }}$

\subsubsection{Acordul trebuie să rezulte din mediere}

În ceea ce priveşte terminologia utilizată în cuprinsul Convenţiei de la Singapore, redactorii tratatului au optat pentru un termen „umbrelă” ${ }^{34}$. În

\footnotetext{
${ }^{29}$ Art. 4 alin. (1) din Convenția de la Singapore.

30 T. Schnabel, op. cit., p. 32.

${ }^{31}$ Art. 4 alin. (1) lit. b) din Convenția de la Singapore.

${ }^{32}$ Art. 6 din Convenția de la Singapore.

${ }^{33}$ Articolul 1 alin. (1) din Convenția de la Singapore.

${ }^{34}$ Idem.
} 
conformitate cu definiţia cuprinsă la art. 2 pct. 3 din Convenţia de la Singapore, medierea desemnează procesul, indiferent de denumirea pe care îl poartă sau izvorul său, prin care părţile încearcă să ajungă la o soluţionare amiabilă a diferendului dintre ele prin intermediul unuia sau mai multor mediatori, care nu pot impune o soluţie părţilor.

Ori de câte ori acordul la care părţile au ajuns nu este rezultatul unei proceduri care să poată fi caracterizată ca fiind o mediere (procedură amiabilă de soluţionare a litigiului, intermediată de un terţ care nu poate impune o soluţie părţilor ${ }^{35}$ ), Convenţia de la Singapore nu este aplicabilă. Sunt excluse astfel din câmpul său de aplicare acordurile de mediere care au fost încuviinţate de către o instanţă de judecată sau care au fost încheiate în cadrul procedurilor desfăşurate în faţa instanţelor de judecată şi care sunt executorii ca hotărâre judecătorească în statul instanţei care a încuviinţat acordul părţilor ( art. 3 lit. a) din Convenţia de la Singapore). Raţiunea instituirii acestei excepţii a fost aceea de a evita suprapunerea cu domeniul de aplicare a Convenţiei de la Haga şi de a nu oferi părţilor posibilitatea de a alege între aceste două instrumente internaţionale ${ }^{36}$. Pentru identitate de raţiune a fost reglementată prin art. 3 lit. b) din Convenţia de la Singapore şi excluderea din domeniul de aplicare a acordurilor care au fost înregistrate şi sunt executorii ca hotărâre arbitrală, fiind avut în vedere, de această dată, domeniul de aplicare a Convenţiei de la New York.

Din perspectiva Convenţiei de la Singapore nu prezintă relevanţă dacă acordul este rezultatul unei medieri $a d-h o c$ sau procedura a fost administrată prin intermediul unei instituţii specializate ${ }^{37}$, şi nici dacă părţile au recurs la procedura medierii voluntar sau aceasta a fost una obligatorie, impusă prin lege sau de către o instanţă de judecată $\breve{~}^{38}$.

În condiţiile dezvoltării soluţionării alternative a litigiilor online, rămâne deschisă întrebarea dacă algoritmilor inteligenţei artificiale prin intermediul cărora sunt soluţionate litigiile online le pot fi acordate valenţe umane, şi măsura în care se poate considera că procedura online a fost intermediată de un mediator ${ }^{39}$.

\subsubsection{Acordul de mediere să fie încheiat în scris}

Acordul de mediere poate fi consemnat într-un înscris sau poate fi încheiat prin mijloace electronice. Oricare dintre aceste două modalităţi îndeplineşte exigenţele Convenţiei de la Singapore.

Conform art. 2 pct. 2 din Convenţia de la Singapore:,, un acord de mediere este încheiat în scris dacă conţinutul său este consemnat sub orice formă" ${ }^{\prime \prime}$.

${ }^{35}$ S. Chong, F. Steffek, op. cit, p. 458.

${ }^{36}$ T. Schnabel, op. cit., p. 25.

${ }^{37}$ C. Jura, op. cit..

${ }^{38}$ T. Schnabel, Implementation of the Singapore Convention: Federalism, Self-Execution, and Private Law Treaties (January 22, 2019). 30 Am. Rev. Int'l Arb., 265 (2020), p. 267, [Online] la https://ssrn.com/abstract=3320823, accesat 30.10.2021.

${ }^{39}$ Idem, pp. 258-259.

${ }^{40}$ Art. 2 pct. 2 teza întâi din Convenția de la Singapore. 
3.1.2.1. Acordul de mediere încheiat prin mijloace electronice

Acordul de mediere poate fi încheiat şi prin mijloace electronice. În viziunea Convenţiei de la Singapore, o comunicare electronică satisface cerinţa formei scrise a acordului de mediere dacă informaţia pe care o conţine este accesibilă ulterior ${ }^{41}$.

Definiţia comunicării electronice cuprinse în Convenţia de la Singapore este expresia aplicării principiului echivalenţei funcţionale pe care UNCITRAL a afirmat-o la nivelul reglementărilor sale din domeniul comerţul electronic internaţional ${ }^{42}$, fiind o preluare a art. 9 alin. (2) din United Nations Convention on the Use of Electronic Communications in International Contract ${ }^{43}$ : „o comunicare electronică satisface această cerinţă dacă informaţia pe care o conţine este accesibilă pentru a fi consultată ulterior" "44. Această abordare o regăsim şi în UNCITRAL Model Law on International Commercial Mediation and International Settlement Agreements Resulting from Mediation, 2018 ${ }^{45}$, dar şi în UNCITRAL Model Law on International Commercial Arbitration ${ }^{46}$.

Având în vedere aceste constatări, apreciem că prevederile Convenţiei de la Singapore cu privire la forma electronică a acordului internaţional de mediere ar putea fi aplicate având ca model interpretările şi soluţiile jurisprudenţiale existente referitoare la forma electronică a convenţiei arbitrale internaţionale. Conform Ghidului ICCA pentru interpretarea Convenţiei de la New York din $1958^{47}$, cerinţa formei scrise este îndeplinită în cazul tuturor comunicărilor care sunt consemnate în scris.

Se consideră că îndeplineşte cerinţa Convenţiei de la Singapore cu privire la încheierea acordului de mediere în scris printr-un schimb de e-mail-uri între părţi sau împrejurarea în care acordul părţilor nu este cuprins într-un document unic ${ }^{48}$. De asemenea, satisfac exigenţele Convenţiei de la Singapore şi acordurile de mediere rezultate ca urmare a soluţionării litigiului prin intermediul platformelor

${ }^{41}$ Art. 2 pct. 2 teza a doua din Convenția de la Singapore

${ }^{42}$ N.Y. Morris-Sharma, op. cit., p.499.

${ }^{43}$ Convenția a fost adoptată în 23 noiembrie 2005 și a intrat în vigoare la 1 martie 2013. Textul convenției este disponibil [Online] la https://uncitral.un.org/sites/ uncitral.un.org/files/media-documents/uncitral/en/06-57452_ebook.pdf, accesat 10.09.2021; S. Chong, F. Steffek, op. cit., p. 467.

${ }^{44}$ Art. 9 alin. (2) din United Nations Convention on the Use of Electronic Communications in International Contract.

${ }^{45}$ Art. 16 alin. 6 din Legea model.

46 UNCITRAL Model Law on International Commercial Arbitration 1985 With amendments as adopted in 2006, [Online] la https://uncitral.un.org/sites/ uncitral.un.org/ files/media-documents/uncitral/en/19-09955_e_ebook.pdf, accesat 10.09.2021; Art. 7 alin. (4) din UNCITRAL Model Law on International Commercial Arbitration 1985 with amendments as adopted in 2006.

${ }^{47}$ Consiliul internaţional pentru arbitraj comercial, Ghidul ICCA pentru interpretarea Convenției de la New York din 1958, Un ghid pentru fudecători, p. 53, [Online] la https://cdn.arbitration-icca.org/s3fs-public/document/media_document/icca_guide_ nyc_romanian.pdf, accesat 29.10.2021.

${ }^{48}$ T. Schnabel, op. cit., p. 28. 
online (întâlnirile online, instant text messaging sau medierea litigiilor care pot avea sau nu la bază algoritmi ai inteligenţei artificiale $)^{49}$.

În cazul acordului de mediere încheiat prin mijloace electronice, condiţia semnării de către părţi sau de către mediator este îndeplinită dacă este utilizată o metodă de identificare a părţilor sau a mediatorului pentru a le indica voinţa cu privire la informaţiile conţinute în comunicarea electronică. Metoda utilizată trebuie să fie o metodă potrivită scopului pentru care respectiva comunicare electronică a fost creată sau transmisă, luând în considerare toate circumstanţele, inclusiv orice acord relevant şi trebuie să fie o metodă care îndeplineşte aceste funcţii singură sau împreună cu alte mijloace de probă ${ }^{50}$.

\subsubsection{Acordul de mediere să soluţioneze un litigiu comercial}

Convenţia de la Singapore nu defineşte sintagma „litigiu comercial”. În această ipoteză, un instrument util se dovedeşte Legea model. În înţelesul Legii model, termenul „comercial” ar trebui interpretat în sens larg pentru a putea cuprinde chestiuni legate atât de relaţii contractuale, cât şi noncontractuale. Prin relaţii de natură comercială se înţelege, fără a se limita la acestea, furnizarea de bunuri şi servicii, asigurări, servicii de consultanţă, investiţii, operaţiuni bancare, acorduri de exploatare sau concesionare, transportul de mărfuri sau pasageri pe cale maritimă, feroviară, aeriană sau rutieră ${ }^{51}$.

Convenţia de la Singapore nu se aplică acordurilor de mediere încheiate pentru a soluţiona un litigiu în care una dintre părţi are calitatea de consumator sau un litigiu referitor la relaţiile de familie, succesiuni sau de dreptul muncii. Această excepţie este reglementată expres prin art. 2 din Convenţia de la Singapore.

\subsubsection{Acordul de mediere să soluţioneze un litigiu comercial internaţional}

La momentul încheierii acordului de mediere, litigiul pe care îl soluţionează trebuie să fie internaţional ${ }^{52}$. Convenţia de la Singapore utilizează în legătură cu acordul de mediere termenul de „internaţional” şi nu termenul „străin” care figurează în textul Convenţiei de la New York în legătură cu hotărârile arbitrale. Opţiunea redactorilor a avut în vedere împrejurarea că spre deosebire de arbitraj, în cazul medierii nu există un loc al medierii ${ }^{53}$.

Criteriile internaţionalităţii litigiului sunt redate în art. 1 din Convenţia de la Singapore. Astfel, litigiul este internaţional în două situaţii: 1) cel puţin două părţi ale acordului de soluţionare a litigiilor au sediul în state diferite sau 2) în

${ }^{49}$ S. Chong, F. Steffek, op. cit., p. 467.

${ }^{50}$ Art. 4 pct. 2 din Convenția de la Singapore.

${ }^{51}$ Nota de subsol 1 din UNCITRAL Model Law on International Commercial Mediation and International Settlement Agreements Resulting from Mediation, 2018.

${ }^{52}$ Idem, p. 20.

${ }^{53}$ N.Y. Morris-Sharma, op. cit., pp. 498-499; S. Chong, F. Steffek, op. cit., p. 456; N. Alexander, S. Chong, Why is there no 'seat' of mediation?, [Online] la https://www. researchgate.net/publication/347130807_Singapore_Convention_Series_Why_is_there_no _\%27seat\%27_of_mediation, accesat 29.10.2021; T. Schnabel, Implementation of the Singapore Convention..., op. cit., p. 267. 
situaţia în care părţile acordului de soluţionare a litigiilor îşi au sediul în acelaşi stat, acesta este diferit fie de statul în care este executată o partea substanţială a obligaţiilor, conform acordului de soluţionare fie de statul cu care obiectul acordului de soluţionare a litigiilor are cea mai mare legătură.

\subsection{Ratione temporis}

Convenţia de la Singapore se va aplica numai acordurilor de mediere care au fost încheiate după data ratificării, acceptării sau aprobării cu sau fără rezerve ${ }^{54} \mathrm{de}$ către statul parte la tratatul multilateral ${ }^{55}$.

Pe cale de consecinţă, la nivel internaţional va continua să existe un regim juridic neunitar cu privire la punerea în executare a acordurilor rezultate din mediere. În cazul statelor părţi la convenţie, acordul de mediere va putea fi pus în executare în condiţiile stipulate de Convenţia de la Singapore. Pentru situaţia în care un stat nu a ratificat, aprobat sau acceptat Convenţia de la Singapore, punerea în executare a acordului de mediere va depinde de legislaţia statului în cauză ${ }^{56}$. Este şi cazul statelor membre (SM) ale Uniunii Europene (UE), întrucât, până în prezent, nici UE ca organizaţie regională, nici unul dintre SM nu au aprobat sau ratificat Convenţia de la Singapore. În spaţiul unional rămân incidente dispoziţiile Directivei 2008/52/CE, astfel cum aceasta fost transpusă în legislaţiile SM $^{57}$. Acordul de mediere va îmbracă forma juridică a unui contract, care urmează să fie pus în executare urmând regulile oricărui contract ${ }^{58}$. În ceea ce priveşte acordurile de mediere încheiate prin mijloace electronice, având natura juridică a unor contracte, urmează să fie supuse regimului contractelor electronice şi legislaţiei aplicabile în materie în vigoare la data încheierii lor în spaţiul UE ${ }^{59}$. Cuprins într-

${ }^{54}$ Conform art. 8 din Convenția de la Singapore, un stat parte la convenție poate declara că nu va aplica tratatul acordurilor la care este parte el sau oricare entitate publică sau persoane care acționează în numele unei entități publice (art. 8 alin.1) sau va aplica tratatul doar în măsura în care părțile la acordul de mediere vor fi de acord cu aceasta (art. 8 alin. (2)).

${ }^{55}$ Art. 9 din Convenția de la Singapore.

${ }^{56}$ E. Chua, Enforcement of international mediated settlements without the Singapore convention on mediation, (2019). Singapore Academy of Law Journal. 31, 572-597. Research Collection School Of Law, [Online] la https://ink.library.smu.edu. sg/sol_research/3090, accesat 30.10. 2021.

${ }^{57}$ Conform art. 12 alin. (1) din Directiva 2008/52/CE, termenul de transpunere a fost 21 mai 2011, cu excepția art. 10, pentru care asigurarea conformității trebuie să aibă loc cel mai târziu la 21 noiembrie 2010. Măsurile luate de către SM în vederea transpunerii Directivei 2008/52/CE, precum și legislațiile naționale adoptate în acest scop sunt disponibile [Online] la https://eur-lex.europa.eu/legal-content/RO/NIM/?uri= CELEX:32008L0052, accesat 13.09.2021.

${ }^{58}$ C.T. Ungureanu, Drept internațional privat european în raporturi de comerț internațional, Editura Hamangiu, Bucureşti, 2021, p. 264.

${ }^{59}$ Pentru problematica legată de contractele electronice în dreptul comerțului internaţional, a se vedea C.T. Ungureanu, Dreptul comerțului internaţional, Editura Hamangiu, Bucureşti, 2018, pp. 155-192. 
un act notarial sau hotărâre judecătorească şi dobândind valoarea unui titlu executoriu, acordul de mediere va putea fi pus în executare în SM conform prevederilor Regulamentului (UE) nr. 1215/2012, fără a fi necesară o hotărâre de încuviinţare a executării ${ }^{60}$.

Deşi aprobarea acestui tratat multilateral de către UE ca organizaţie economică regională nu ar reprezenta o premieră, UE devenind anterior parte şi în alte convenţii internaţionale (exempli gratia, Convenţia de la Haga), acest moment nu pare a fi unul situat într-un viitor foarte apropiat. UE şi-a urmărit propria agendă în materia reglementării medierii în domeniul relaţiilor comerciale transfrontaliere, continuând procesul legislativ atât în timpul negocierilor purtate pentru elaborarea Convenţiei de la Singapore, cât şi după adoptarea acesteia. În UE au fost adoptate în perioada referită Regulamentul (UE) 2019/1150 al Parlamentului European şi al Consiliului din 20 iunie 2019 privind promovarea echităţii şi a transparenţei pentru întreprinderile utilizatoare de servicii de intermediere online $^{61}$ şi Directiva (UE) 2019/633 a Parlamentului European şi a Consiliului din 17 aprilie 2019 privind practicile comerciale neloiale dintre întreprinderi în cadrul lanţului de aprovizionare agricol şi alimentar ${ }^{62}$.

O altă reglementare unională care prezintă importanţă din perspectiva rezervei pe care un stat sau organizaţiei regională poate să o formuleze în temeiul art. 8 alin. (1) din Convenţia de la Singapore este Acordul privind încetarea tratatelor bilaterale de investiţii dintre statele membre ale Uniunii Europene ${ }^{63}$ care reglementează o formă sui generis de mediere între un investitor şi SM.

\section{Motivele de refuz de recunoaştere a acordului de mediere}

Cererea părţii interesate adresată autorităţii competente a unui stat parte la Convenţia de la Singapore pentru punerea în executare a acordului de mediere poate fi refuzată pentru motivele limitativ prevăzute la art. 5 din Convenţia de la Singapore.

Spre deosebire la prevederile Convenţiei de la New York în temeiul cărora nevaliditatea clauzei de arbitraj era prevăzută expres în textul tratatului ca reprezentând unul dintre motivele de refuz de executare a sentinţei arbitrale străine, aparent, Convenţia de la Singapore nu prevede acest motiv printre temeiurile refuzului punerii în executare a unui acord internaţional de mediere. $\mathrm{Cu}$ toate acestea, apreciem că lipsa validităţii formale a acordului de mediere poate fi încadrată motivului prevăzut de art. 5 alin. (1) lit. b) subpunctul i): acordul de

${ }^{60}$ Art. 58 și art. 59 din Regulamentul (UE) nr. 1215/2012.

${ }^{61}$ Publicat în JO L 186, 11.7.2019.

62 Publicată în JO L 111, 25.4.2019; Pentru o analiză a medierii între profesioniști conform Regulamentului (UE) 2019/1150, a se vedea C.T. Ungureanu, Drept internațional privat..., op. cit., pp. 266-270 .

${ }^{63}$ Publicat în JO L 169, 29.5.2020; Acordul a intrat în vigoare la 29 august 2020; Pentru o prezentare a acestei proceduri, a se vedea C.T. Ungureanu, Drept internațional privat european..., op. cit., pp. 236-237. 
soluţionare este caduc, inoperant sau nu este susceptibil de a fi pus în executare conform legii alese de către părţi sau în lipsa unei astfel de alegeri, în temeiul legii autorităţii competente a statului parte la convenţie în faţa căreia cererea a fost introdusă în temeiul art. 4 din Convenţia de la Singapore.

Termenii „caduc”, „inoperant”, „,nesusceptibil de a fi aplicată” nu îşi regăsesc o definiţie în corpul Convenţiei de la Singapore. Autoritatea competentă chemată să se pronunţe asupra temeiniciei acestui motiv de refuz de punere în executare sar putea orienta spre explicaţiile pe care aceşti termeni le-au primit cu ocazia interpretării Convenţiei de la New York. În practică, s-a reţinut că excepţia caducităţii se referă la toate situaţiile în care convenţia este afectată de invaliditate încă de la încheierea sa ${ }^{64}$, în timp ce o convenţie este inoperantă dacă a fost valabil încheiată dar şi-a încetat efectele ${ }^{65}$ şi nu este susceptibilă de a fi aplicată în cazul în care nu se poate recurge la mijlocul alternativ de soluţionare a litigiului din cauza unor impedimente juridice sau fizice ${ }^{66}$.

În această bază, partea căreia i se opune o cerere de executare a acordului de mediere ar putea invoca nevaliditatea formală a acordului de mediere încheiat prin mijloace electronice. Autoritatea competentă va trebui să stabilească mai întâi care este legea aplicabilă acordului internaţional de mediere şi apoi să cerceteze condiţiile pe care această reglementare le impune sub aspectul încheierii valide a unui acord de mediere. Dacă părţile au desemnat legea aplicabilă, autoritatea se va raporta la legea aleasă de către părţi. În sens contrar, legea aplicabilă va fi desemnată de autoritatea competentă urmând regulile stabilite în dreptul său intern.

Având în vedere similitudinea reglementărilor din Convenţia de la Singapore cu cele ale Convenţiei de la New York, răspunsul la întrebarea referitoare la stabilirea validităţii formale a acordului de mediere ar trebui urmeze aceleaşi principii şi soluţii judiciare exprimate cu privire la aplicarea art. 5 alin. (1) lit. a) din Convenţia de la New York ${ }^{67}$.

Apreciem că, similar interpretării aplicării condiţiei validităţii impuse din Convenţia de la New York ${ }^{68}$, acest motiv de refuz trebuie invocat de către partea căreia i se opune acordul de mediere şi nu de către autoritatea competentă din oficiu şi dovedit tot de către aceasta şi nu de către partea care solicită executarea.

${ }^{64}$ Consiliul international pentru arbitraj comercial, Ghidul ICCA..., op. cit., p. 55.

${ }^{65}$ Idem, p. 56.

${ }^{66}$ Ibidem.

${ }^{67}$ UNCITRAL Secretariat Guide on the Convention on the Recognition and Enforcement of Foreign Arbitral Awards (New York, 1958) 2016 Edition, pp. 151-152, [Online] la https:/uncitral.un.org/sites/uncitral.un.org/files/media-documents/uncitral/en/2016_ guide_on_the_convention.pdf, accesat 30.10.2021.

${ }^{68}$ Ibidem. 


\section{Concluzii}

Viitorul soluţionării litigiilor de comerţ internaţional aparţine mijloacelor alternative de soluţionare a litigiilor, din care face parte şi medierea. Această tendinţă este una care s-a accentuat în ultimii ani. Istoria aplicării Convenţiei de la New York în ceea ce priveşte recunoaşterea şi executarea hotărârilor arbitrale străine îndreptăţeşte afirmaţia conform căreia succesul Convenţiei de la Singapore va depinde de numărul de state care vor înţelege să adere la această convenţie, de modalităţile concrete în care statelor vor integra în legislaţia naţională prevederile tratatului ${ }^{69}$, precum şi de modul în care practicienii dreptului (avocaţi, mediatori) sau alte părţi interesate vor conştientiza beneficiile soluţionării litigiilor de comerţ internaţional prin mediere ${ }^{70}$.

Totodată, impunerea medierii ca principal mijloc alternativ de soluţionare a litigiilor internaţionale este condiţionată de dezvoltarea unui infrastructuri juridice prin adoptarea unor reguli asupra procesului medierii, a codurile de conduită ale mediatorilor, dar şi de o viitoare jurisprudenţă care să ilustreze aplicarea în practică a Convenţiei ${ }^{71}$.

\section{Referinţe}

Alexander N., Chong S., UN Treaty on mediation signed in Singapore, Nederlands-Vlaams tijdschrift voor mediation en conflictmanagement. 23, (2-3), 71-76, 2019 Singapore Management University School of Law Research Paper No. 14/2020, http://dx.doi.org/10.5553/tmd/138638782019023203008

Alexander N., Chong S., Why is there no 'seat' of mediation?, [Online]

Anderson D. Q., The Singapore Convention on Mediation: Supplying the Missing Piece of the Puzzle for Dispute Resolution, Forthcoming, Journal of the Malaysian Judiciary (Nov 2020), Singapore Management University School of Law Research Paper No. 1/2020, [Online]

Chong S., Steffek F., Enforcement of International Settlement Agreement Resulting from mediation under the Singapore Convention - Private International Law Issues in Perspective, Singapore Academy of Law Volume 31 (2019), [Online]

Chua E., Enforcement of international mediated settlements without the Singapore convention on mediation, (2019). Singapore Academy of Law Journal. 31, 572-597, Research Collection School Of Law, [Online]

Consiliul internaţional pentru arbitraj comercial, Ghidul ICCA pentru interpretarea Convenţiei de la New York din 1958, Un ghid pentru fudecători, [Online]

Franck S. D., Challenges Facing Investment Disputes: Reconsidering Dispute Resolution în International Investment Agreements. Appeals mechanisms in international investment disputes, Karl P. Sauvant, ed., Oxford University Press, 2008, Washington \& Lee Legal Studies Paper No. 2009-03, [Online]

ICSID Arbitration Rules [Online]

${ }^{69}$ T. Schnabel, Implementation of the Singapore Convention..., op. cit., pp. 277-289.

70 T. Schnabel, op. cit., p. 60.

${ }^{71}$ The Singapore International Dispute Resolution Academy, A Handbook on the Singapore Convention on Mediation, p. 25, [Online] la https://www.singaporeconvention. org/sites/singaporeconvention.org/files/SMU\%20SOL\%20Singapore\%20Convention\%20Me diation\%20Handbook.pdf, accesat 12.09.2021. 
Jura C., $O$ introducere în materia Convenţiei Naţiunilor Unite privind Acordurile Internaţionale Rezultate în urma Medierii - Convenţia de la Singapore, în Revista română de arbitraj nr. 1/2020, [Online]

Kessedjian C., Droit du commerce international, Ed. Presse Universitaires de France, Paris, 2013

McCormick K., Ong S.S. M., Through the Looking Glass: An Insider's Perspective into the Making of Singapore Convention on Mediation (2019) 31 Singapore Academy of Law Journal, [Online]

Morris-Sharma N. Y., Constructing the Convention on Mediation: The Chairperson's Perspective (2019) 31 Singapore Academy of Law Journal 487-519, [Online]

Salacuse J. W., Is There a Better Way? Alternative Methods of Treaty-Based, Investor-State Dispute Resolution, în Fordham International Law Journal, Volume 31, Issue 12007 Article 6, [Online]

Schnabel T., The Singapore Convention on Mediation: A Framework for the Cross-Border Recognition and Enforcement of Mediated Settlements (September 18, 2018). 19 Pepp. Disp. Resol. L.J. 1 (2019), http://dx.doi.org/10.2139/ssrn.3239527

Schnabel T., Implementation of the Singapore Convention: Federalism, Self-Execution, and Private Law Treaties (January 22, 2019). 30 Am. Rev. Int'l Arb., 265 (2020), p. 267, [Online]

SIDRA International Dispute Resolution Survey: 2020 Final Report, [Online]

Sîrbu M., Metodele ADR în contextul european şi internaţional, Editura Universul Juridic, Bucureşti, 2020

Steele B. L., Enforcing International Commercial Mediation Agreements as Arbital Awards Under the New York Convention în 54 UCLA Law Review 1385 (2007), pp. 1397-1399, [Online]

Sussman E., The New York Convention Through a Mediation Prism, în Dispute Resolution Magazine Volume 15, Number 4, Summer 2009, [Online]

The Singapore International Dispute Resolution Academy, A Handbook on the Singapore Convention on Mediation, [Online]

UNCITRAL Secretariat Guide on the Convention on the Recognition and Enforcement of Foreign Arbitral Awards (New York, 1958) 2016 Edition, https://doi.org/ 10.18356/661735a6-en

United Nations Conference On Trade And Development, Investor-State Disputes: Prevention and Alternatives to Arbitration II, United Nations New York and Geneva, 2011, [Online]

Ungureanu C.T., Enforcement of the post- mediation agreement in international trade disputes, în „Modernizarea legislaţiei naţionale în contextul uniformizării dreptului la nivel european şi implicaţiile socio-politice asupra sistemului administrativ”, Editura Hamangiu, Bucureşti, 2014

Ungureanu C.T., Dreptul comerţului internaţional, Editura Hamangiu, București, 2018

Ungureanu C.T., Drept internaţional privat european în raporturi de comerţ internaţional, Editura Hamangiu, București, 2021 